\title{
Innovation and Practice of the Group Mode in Vocational Education
}

\author{
Gui-Yan SUN* \\ Liaoning Railway Vocational and Technical College, Jinzhou, Liaoning 121000, China \\ sgylnjz2006@163.com
}

Keywords: Vocational education group, One enterprise, Three schools, Educate students, Cooperatively.

\begin{abstract}
Liaoning Railway Transport Vocational Education Group commits to the innovative group mode of operation. The school has established the "one enterprise, three schools" cooperation alliance to form a cross-regional joint development of school-enterprise consortia. It also sets up a school-enterprise communication platform, forming personnel training mode and innovative new workers Pre-job training, which receives significant results and becomes a model to other schools.
\end{abstract}

\section{The Background}

\section{Review of Liaoning Railway Transport Vocational Education Group}

According to the spirit of the State Council's Decision on Speeding up the Development of Modern Vocational Education, "full use of the important role of vocational education groups should be made in promoting the organic integration of the education chain and the industrial chain; and encouraging central enterprises and leading enterprises in the industry to take the lead in setting up vocational education groups." Based on the Opinions of the Ministry of Education on Further Promoting Collectivized Operation of Vocational Education, "the development of modern vocational education should be sped up;and deepening collectivized operation should be regarded as an important direction." The Liaoning railway transport vocational education group is set up after several researches and demonstrations, which are hosted by Liaoning Railway Vocational and Technical College, Liaoning Province Department of Education. The chairman of the group is the Shenyang Railway Bureau leadership. Supported by the railway and urban rail transit industry, the Group has 3 affiliated colleges, 6 vocational and tertiary institutions, 4 vocational and technical secondary schools, 9 training institutions and research institutes, and more than 50 enterprises.

Liaoning Railway Vocational Technical College is founded in 1952. It has been founded for 65 years. The school has a long history of running well with rich experience, good social reputations, and heavy accumulation of how to run a school well. Since its foundation, the school has trained nearly 50,000 people of various management and technical talents at all levels for railways and local enterprises. The school has opened up 32 professionals, which is corresponding to the railway and urban rail industry operating system, signal control system, power supply system, maintenance system, vehicle power system, communication information system and line construction and maintenance system and so on. It has now completed one national demonstration professional, one state-level ICT industry innovation and 7 provincial demonstration specialties. The school always adheres to the school-running goal of "distinguishing features, first-class industries, demonstrating in the province and satisfying the society" and adheres to the development strategy of "building the school with characteristics and high quality, running the schools with speciality and strengthening the school with talents". All of the work has reached anticipating results.

\section{The Background of "One Enterprise, Three Schools" Cooperation Alliance under the Group}

As the cooperation between schools and enterprises is not close enough, there is no institutional mechanism of "school-enterprise cooperation, combination of work and learning, mutual complementary of advantages, resources sharing and win-win progress", which causes schools to adopt personnel training mode, curriculum, construction of teaching staff and practical training inside and outside the school base construction and post-graduate internships, employment and 
other aspects. Thus, it is difficult to achieve effective connections with enterprises. The advantages of the school can not be effectively played, and school-enterprise cooperation has been that of one-sided enthusiasm[1].

There are more than 210,000 serving workers in Shenyang Railway Bureau now, and economically attracts areas for Liaoning and Jilin provinces as well as parts of Inner Mongolia, Heilongjiang and Hebei provinces. Further achievements will be achieved in the next five years. The overall railway mileage will reach $14,100 \mathrm{~km}$, so it is in urgent need of large quantities of high-quality skilled persons. Due to the serious aging trend of skilled persons on the vital position in railway, the low qualifications of technical workers and their lack of professionalism have further aggravated the shortage of job-seekers. To some degree, the overall skill level of railway front-line skilled workers determines the potential for the development of the railway industry. However, skillful workers aremainly from vocational collegesmust undergo pre-job training before they start their jobs. On the one hand, this could not help to solve the shortage of workers. On the other hand, it could increase investment in enterprise personnel training. This is not conducive to the development of enterprises, and has become a difficult problem for enterprises to endeavor to solve.

In order to deepen the reform of vocational education, strengthen the construction of modern vocational education, stimulate the vitality of vocational education and improve the ability to serve the local economic and social development[2], Liaoning Railway Transport Vocational Education Group focuses on the needs of enterprises, meets the needs of enterprises and focuses on cultivating practical skills talents. The "one enterprise, three schools" alliance established by Shenyang Railway Bureau, Liaoning Railway Vocational and Technical College, Jilin Railway Vocational and Technical College and Liaoning Rail Vocational College, forms a joint development community of school-enterprise cooperation across regions. It is also a platform to educate students, select people, and employ people[3]. It is a good chance for graduates to dockwith enterprises, so that the school-enterprise cooperation could go deeper, into the essence, and become a model.

\section{The Implementation Process}

In order to deepen the reform of vocational education, strengthen the construction of modern vocational education, stimulate the vitality of vocational education and improve the ability to serve local economic and social development, Liaoning Vocational College of Railways set up a cooperation alliance of "one enterprise, three schools" and set up "barrier-free" school-based enterprises communication platform to form a "zero distance" docking personnel training mode and to innovate new staff pre-job training methods. This could be an important contribution to innovations in the shortage of personnel in railway enterprises, and finally receives remarkable results.

\section{Make Sure of the Overall Plan}

Liaoning Railway Transport Vocational Education Group first conducts a theoretical exploration to ensure that "one enterprise, three schools" cooperation alliance to nurture talent feasibility; establishes institutional mechanisms to ensure the operability of "one enterprise, three schools" cooperation alliance to nurture talents; makes a clear division of responsibilities, andensures the implementation of "one enterprise, three schools" cooperation alliance to nurture talent; ensures that the "one enterprises, three schools" cooperation alliance cultivates talented personnel.

\section{Make Clear of Implementation Methods}

\section{Take the Initiative to Advocate}

Under the new situation of innovation and development of vocational education, the Group takes the initiative to advocate active services, strengthen the concept of active services, and explore the path to active services. It actively promotes the participation of industry enterprises in vocational education with active services, sincere services and pragmatic services. The active participation, the deepen participation and continuing to participate enables the formation of a new normal in 
school-enterprise cooperation, which could not only help enterprises in innovation and development, but also stimulate the vitality of school running.

\section{Active Planning}

The Group plans carefully, explores actively and carries out the cooperation between schools and enterprises effectively so as to realize the integration of production and teaching. In the process of proactively fitting into the enterprises, the leading unit of the Group, the Liaotie Iron and Steel Institute, acutely captures the urgent need to solve the problem caused by the advancement of the Shen Bureau in employing and the new staff pre-service training. Furthermore, Liaotie Iron and Steel Institute regards them as a starting point, plansa new chapter in cooperation between school and enterprises, and sets up to promote innovation and development of the big stage. Concept first, Shen Bureau carries out the theoretical study of solving problems; basis supports, it has set upseven major types of professional groups of railway schools, firms, and enterprises professional construction council; precision force, sets up to co-educate people for the purpose of "one enterprise, three schools" school-enterprise cooperation alliance.

\section{Sincere Cooperation}

In the process of proactively fitting into enterprises and serving enterprises, the multi-resources of schools are constantly pouring to the enterprises, impressing enterprises and winning cooperation with active attitude in serving and problem solving. Meanwhile,schools are trying hard to absorb fresh nutrients from the practice of enterprises, thus,there forms a positive interaction with quality resources between schools and enterprises.

\section{Pay Attention to Pragmatic Effect}

In the process of "one enterprise, three schools" cooperation, the Group insists on the problem orientation, sincerely hopes to achieve something to help the enterprises, always thinks about the enterprises and finally solves the difficulties of the enterprise.While winning the recognition, trust and dependence of enterprises, schools should work together with railway enterprises from enrollment to employment. The Group is supposed to keep the scale of students' enrollment and the quality of graduation and employment. As a result, graduates that are educated by schools and enterprises could find good jobs that meet the satisfaction of enterprises, schools, their parents and the society.

\section{Ensure Smooth Implementation}

\section{Organizational Security}

The Group sets up a "one enterprise, three schools" cooperation committee. Members of the cooperation committee are composed of enterprises and institutions designated personnel; the secretariat is located in Shenyang Railway Bureau Labor and Health Department. The committee is mainly responsible for coordinating the work of school-enterprise cooperation, organizing seminars, negotiating cooperation issues, formulating cooperation projects, promoting the implementation of cooperation projects and assessing the effectiveness of cooperation.

\section{System of Protection}

To strengthen management and improve the system is an important guarantee for ensuring the smooth progress of the "one enterprise, three schools" cooperation alliance and realizing the in-depth integration.

\section{Put into Protection}

Based on the cooperation contents and work plan of "one enterprise, three schools", the Group will compile the capital budget and ensure the capital investment; formulate the work plan to ensure the input of resources such as teachers, equipment, technology and volunteer services so as to ensure the cooperation of "one enterprise, three schools" to carry out successfully and all activities of the project work effectively. 


\section{Cooperate in an Orderly Manner}

Taking advantages of the opportunity to participate in the teaching steering committee of vocational education in Beijing's railway industry, the school proposes that the leadership of Vocational Education Department of Shenyang Railway Administration and the three vocational colleges are supposed to negotiate, innovate and cooperate with each other to make the cooperation better.

The first cooperation seminar.The Group establishes the "thematic framework for cooperation between schools and enterprises", construct a coordination mechanism for the cooperation between regional enterprises and schools, makes the responsibilities and obligations of both schools and enterprises in cooperation clearly, and proposes the orientation training for pre-contracted personnel requests.

The second symposium. After studying and discussing, the Group formulatesthe "one enterprise, three schools" Implementation of the Cooperation Framework, further clarify the goal of school-enterprise cooperation, identify the school-enterprise cooperation that are to build a brand specialty, build internship training bases and teaching stuff, co-develop teaching materials and teaching courseware software, cooperate in scientific researches and technology researches, cooperate in organizing skills competitions, work together to train corporate employees and orient personnel training, co-manage student internships, build passenger volunteer service team and such a total of ten elements.

The third seminar.The Group divides the ten elements to the leading companies of school-industry cooperation, discuss the details respectively, and finally arrange the summer volunteer internship with vocational colleges.

The fourth seminar.After researching and studying, the Group identifies the teaching plan of pre-contracted personnel oriented training, determine the training mode of " $2+0.5+0.5$ ", revise the Measures for Students' Skills Competition in Vocational Colleges and Institutions, and review the brand specialty of colleges and enterprises, and framework oftraining basis.

The fifth seminar. The Group hasadopted the Measures for the Management of Qualified Personnel Development in "One Enterprise and Three Schools" and the Measures for the Administration of Professional Skill Competition for Students in "One Enterprise and Three Schools". According to the Contents of Cooperative Implementation Plan for "One Enterprise and Three Schools", the Group formulates various methods of cooperation projects implementation and rules of related works.

The sixth seminar.The Group sets up the committee of Liaoning Railway Transport Vocational Education Group School-enterprise cooperation and personnel training and professional construction; build up eight professional construction teams; ensure 20items of skills competition, 10 of which will be hold in 2017; determine the cooperative development of 29 textbooks.

The seventh seminar.The Group studies the school-enterprise cooperation in the development of teaching courseware; consider the adoption of seven school-enterprisecooperation teaching and research topic opening report.

The eighth seminar. The Group considers 29 school-enterprise cooperation teaching materials to prepare syllabus and textbook draft;determine the publication time.

"One Enterprise, Three Schools" annual working summary. The Group has summedup the major work carried out by "one enterprise, three schools" over the past year, and the achievements and experiences that are worth summarizing; and further deepened the cooperation of "one enterprise, three schools" and the deployment of the next phase of work.

The Group has held a two-month skills competition among the three schools students. There are 15 items in the competition, which covers 7 railway fields. The directors are experts of the enterprises. Besides, there are 239 competitors win prizes and 38 instructors win the reputation of excellent instructors. 


\section{Special Innovation}

\section{Innovate the Mode of Running a Vocational School}

In the practice of group education of vocational education, the Group accumulates experience, explore ways of organization actively, and set up a cooperation alliance of "one enterprise, three schools" in accordance with local conditions to realize the cooperation between two provinces (Liaoning and Jilin province), three places (Shenyang, Jinzhou, and Jilin) and four directions (enterprise, three schools) in cross-regional joint education resources. Through the collectivization of the form, especially the effective participation of industry and enterprises, the teaching chain of schools could catch up with the benefit chain of the enterprise and form a network of personnel training, graduates employment, mutual recruitment of staff and staff training. Furthermore, it could form an integrated running school model, give full play to the scale of vocational education group efficiency, and continuously enhance the ability of vocational education for the development of regional economy.

\section{Innovate the Personnel Training Mode}

Vocational colleges and enterprises are the main participators in vocational education groups. Inter-school cooperation within the group is conducive to expanding students' learning and living spaces, which could make the original relatively closed environment more open, and some other issues could be solved such as information asymmetry between schools and enterprises, personnel training goals and business needs out of line. In the practice of running a school, the "one enterprise, three schools" cooperation alliance has changed the traditional mode of teaching management and jointly developed and cooperated with each other in terms of professional settings, curriculum development, teaching plan formulation, teaching material compilation and skill competition. The group could maximize the use of school resources to cultivate the most high-quality talent closest to business needs.

\section{Innovate Staff Pre-Job Training Model}

Graduates in the three schools that are pre-assigned to Shenyang Railway Bureau will be assigned to other related enterprises in Shenyang, and the new staff training will be arranged in the last semester before graduating. They will combine the post-graduate internship with post-graduate pre-job training together, which will be completed by the railway enterprises and the schools. This could enable students to work more quickly.

Schools and enterprises make the management systemfor post-graduate internships respectively. They make certain rules of the student's internship attitude, performance, daily management and performance appraisal. Road Bureau also gives comprehensive assessment rankings of students in school units, and it send the results to schools regularly, which could make schools pay more attention to their studentson-site internships. The school send professional teachers to visit enterprises regularly, keep abreast of the internship performance of students, solicit employers for school teaching and management advice and suggestions.

Through the concerted efforts of school-enterprise management, post-graduate student internships and pre-job training realize an effective combination, whichcan reduce the training costs of enterprises. More importantly, the appointment of employment of students go ahead of the original time greatly. This could not only help to meet the business needs of employees and reduce labor costs, but also create conditions for students to become the backbone of enterprises as soon as possible.

\section{Service Capabilities and Operational Effectiveness}

\section{Established a "Barrier-Free" School-Enterprise Communication Platform}

Through regular seminars, the Group has established a "barrier-free" school-enterprises and school-school communication mechanism. Especially in the enterprise aspect, the Group not only has the vocational education department, but also has labor department, personnel department and 
various business units,so that the school can keep abreast of the standards of the demands and skills required by each type of job and posts in various fields in the coming years; the enterprises should timely grasp the professional settings of each vocational colleges, the level of teachers and the training of qualified personnel; communicate with each other and improve each other through common improvement to received good results.

\section{Formed an Effective Docking of Personnel Training Mode}

Through enterprise participation in school construction and formulation in school enrollment,schools could develop and promote docking between professional settings and industry needs, the course content and job standards, so as to improve the school service delivery of production-oriented enterprises. Through the communication between school and enterprise, the training mode of " $2+0.5+0.5$ " was established. In the first two years, four basic semesters of basic professional knowledge and basic skills were completed in the school. In the fifth semester, based on the needs of enterprises, the Group has strengthened the training of job knowledge and skills for those assigned students. In the sixth semester,students were arranged by the enterprises to the future jobs for pre-job training and post or internship, which achieved the school teaching and business needs close docking.

\section{Created a Brand Close to the Professional Business}

In order to build an application-oriented high-skilled personnel training base that has the characteristics of Shenyang Railway Bureau, stable and high-quality, and adapts to the new railway equipment technology, the Group has ensured the effective docking of schools and enterprises. According to the demand of transportation and production jobs, the Group has identified 8 major specialties: High-speed railway passenger service, railway traffic management, railway locomotives, EMU overhaul technology, railway vehicles, railway engineering technology (three in one), automatic control of railway signals, railroad power supply technology (network integration). Based on the students' future employment positions, experts from various Shenyang Railway Administration business offices checked and all vocational schools promptly adjusted the personnel training programs, revised the teaching plans and optimized the curriculum standards.

\section{Enhance theConstruction Level of the Training Base}

In order to improve the training base construction level, experts in vocational colleges and road bureaus discuss and then demonstrate the feasibility of building programs. With the help of enterprise network resources, they can choose the best equipment manufacturers, determine the lowest price. In accordance with the production environment of enterprises to build training base, they could improve the usage of the resources in a large scale. The Bureau of Railway Administration give equipment support to the school, which could ensure that the training base is equipped with advanced and pragmatic equipment, and close to the site. With the joint efforts of schools and enterprises, the construction of training bases for three vocational colleges has been greatly improved.

\section{Play potential Advantagesof both Schoolsand Enterprises}

Through the close cooperation between schools and enterprises, enterprises directly participate in the construction of schools, select experts to revise talent cultivation programs, demonstrate training base construction programs, attend in independent enrollment interviews, select part-time teachers for schools and preside over examinations so that vocational colleges will be benefited a lot.

Vocational colleges arrange teachers to have courses actively, to teach the staff in training basesand the grassroots station training. This could improve the technological level of workers and ensure that enterprises transport production is not affected.In the meantime, teachers could receive practical exercises, and will be welcomedby enterprises and schools.

Some high-level professional teachers have become technical advisers to the railway administration. They often provide technical services to railway sites, help them solve technical problems, participate in the revision of rules and regulations, and serve as coaches in the railway 
industry skills competitions. They also attend in the research on enterprises through various channels.

\section{Improve the Quality Evaluation System}

The Group conducts regular evaluations of graduates, collects follow-up surveys of graduates from enterprises and employs business experts to attend in the evaluation of the quality of teaching in schools.In addition, the Group identifies problems and makes feedback in a timely manner, and continuously conducts teaching reform and adjustment, thereby enhancing the overall quality of the Group's personnel training and school efficiency.

\section{The Development Prospects}

\section{Establish a Sound Mechanism to Ensure the Sustainable Development of the Group}

The Group should continue to establish and improve its operating mechanism with clear responsibilities, co-ordination, integration and efficient operation[4]. The Group must improve democratic decision-making and the dynamic adjustment mechanism of member units, which could ensure the sustainable development of the Group.

\section{InnovateIdeas for Running Schools to enhance the Construction of the Group}

In the future, the Groupare supposed to analyze and summarize the typical cases of the "one enterprise, three schools" cooperation alliance. According to systematic practice analyses and theoretical researches, the Group will continue to innovate the way of running schools, optimize the external environment and improve the integration between schools and enterprises. This is of great significance in improving the connotation construction of the Group. Therefore, the Group can take up the task of integrating the education chain and the industrial chain practically, stimulating the vigor of running schools and improving the quality of running schools.

\section{Grasp the Development Trend and Enhance the Effectiveness of the Group}

In order to enhance the operational efficiency of the Group's mode of running a school, the Group should study the developing rules and directions[5]. In this way, the Group will take the right path and develop faster, higher and stronger.

\section{Conclusion}

All in all, carrying out the group operation of vocational education is a major measure to deepen the integration of production and teaching, the cooperation between schools and enterprises, stimulate the vitality of vocational education, and promote the open sharing of quality resources[6]. This is of great significance to promote the construction of a modern vocational education system, training high-quality skilled personnel systematically and serving the regional economic development[7]. On the basis of summing up the successful experience of the "one enterprise, three schools" cooperation alliance, Liaoning Railway Transport Vocational Education Group will continue to explore and try its best to cultivate more excellent talents for the society.

\section{References}

[1]BingLI,On the new pattern of college-enterprise double mainstay cooperation snd integrated training,Journal of Liaoning vocational.2015(9)7-8.(In Chinese)

[2]Li-huaJiang.The Construction of Model Vocational Education Groups from Perspectiveof Modern Vocational Education System.Adult Education ,2014(12):77-79.(In Chinese)

[3]Zhi-bingLiu,Ming-ceLiu,Jian-biaoYin.Discussion on Operational Mechanism of School-runningofVocationalEducationGroupofJiangxiProvince.Vocational and Technical Education,2012(29):45-52.(In Chinese) 
[4]Ru-Zhe LUO.Construction of Lasting Effect Mechanism for School-enterpriseCooperation under the School-running Model of Vocational EducationGroup.Vocational and Technical Education,2012(6):34-38.(In Chinese)

[5]kai MA.Research on the Policy Assurance of SchoolRunning Mode of Transportation Vocational Education Group.Co-Operative Economy \& Science,2015(7):78-79. (In Chinese)

[6] Jian-Lu Chen,Zu-Mei Lin.A Review on the Development of Vocationgal Education by Corporate Groups in China.Journal of Hebei Normal University(Educational Science Edition),2015(7):58-63. (In Chinese)

[7]YueXU,Jing GUO.Review and Thinking of the Grouping of Vocational Education in China.Chinese Vocational and Technical Education,2017(3):92-96. (In Chinese) 